\title{
Ecological Wisdom Oral Tradition in West Sumatra Oil Palm Plantations as BIPA Material
}

\author{
Khairil Anwar' ${ }^{1}$ Ferdinal $^{2}$, and Rima Devi ${ }^{3}$ \\ Universitas Andalas, Indonesia \\ ${ }^{1}$ khairilanwar@hum.unand.ac.id, ${ }^{2}$ ferdinal@hum.unand.ac.id, \\ 3rimadevi@hum.unand.ac.id
}

\begin{abstract}
This study is about ecological wisdom of oral traditions in oil palm plantations in West Sumatra as BIPA learning material in revitalization efforts. This thought departs from the global issue that oil palm is the prima donna of world energy and its impact on oral traditions in plantation expansion areas. This qualitative research began with the documentation of oral traditions and continued with analyzing the content of ecological wisdom. This work is guided by theories and methods of cultural materialism, which views oral tradition as part of the social structure that governs human interaction with nature. Wisdom is a panorama of language and literature that can be used as an alternative BIPA learning material as well as a strategic medium for global revitalization. The learning material consists of contextuality, form, function, and the role of ecological wisdom in human life and the future of the earth given in class; and BIPA learner field studies to natural sites in the oil palm plantation area of West Sumatra that have undergone changes. Of course, the material is a reinforcement for BIPA learners in mastering Indonesian
\end{abstract}

Keywords: Tradition, Ecology, Plantation, Values, and BIPA

\section{PENDAHULUAN}

Ekspansi perkebunan sawit terjadi di mana-mana di Indonesia. Secara nasional dan global sawit menjadi komoditas idola. Bagi perekonomian Indonesia, menjadi pendapatan dan penyedia lapangan kerja yang signifikan. Sumatra Barat bagian wilayah ekspansi tersebut. Keberadaan kebun sawit membawa perubahan signifikan pada ekonomi. Hal itu berpengaruh pada pola pikir dan cara hidup masyarakat. Secara langsung berdampak pada kebudayaan. Perubahan pada sendi-sendi kebudayaan yang menjadi norma interaksi manusia dengan lingkungan. Bahkan, kepunahan yang disebabkan hilangnya tradisi lisan akibat ekspansi perkebunan sawit.

Ekspansi perkebunan sawit mencapai titik kritis. Hal itu menarik perhatian berbagai kalangan. Respon yang muncul melogosentriskan aspek kemanusiaan dan kebudayaan, seperti tersingkirnya masyarakat asli (indigenous people) dan masyarakat adat (tribal people). Mereka secara turun-temurun tinggal dan hidup di hutan, sekarang, seiring eksploitasi hutan, 
kedaulatan dan akses mereka terhadap sumber daya alam terampas[1]. Tradisi yang menjadi norma interaksi manusia dengan lingkungan terdegradasi.

Tradisi lisan merupakan aspek kebudayaan yang mengandung nilai-nilai ekologis yang dikukuhkan dalam bentuk mitos dan legenda. Tradisi lisan kaya akan bahasa dan sastra dengan keanekaragaman yang mengesankan. Kekayaan itu membentuk panorama, lanskap atau taman kebahasaan dan kesastraan. Cerita lisan itu merupakan kekayaan khas budaya setempat. Walaupun ekspansi perkebunan sawit tak terhindarkan dan menyebabkan kepunahan, namun masih tersimpan dalam memori kolektif masyarakatnya. Hal itu menjadi bukti untuk menunjukkan tradisi yang pernah ada dan situs ekologi yang menjadi lokasi sumber energi dan protein masyarakat. Oleh karena itu, revitalisasi perlu dilakukan. Salah satunya, dilakukan dengan menjadikan muatan pembelajaran, sekaligus wujud kontribusi kajian kebudayaan terhadap pengajaran Bahasa Indonesia bagi Penutur Asing.

Pembelajaran BIPA berbasis tradisi lisan ekologis merupakan salah satu cara membantu pelajar mencapai standard kompetensi penguasaan bahasa Indonesia. Selain itu, pelajar mendapat pengetahuan tentang kearifan ekologis di Indonesia dan ini mejadi salah satu strategi dalam memberikan pemahaman terhadap tradisi lisan di daerah perkebunan sawit di Indonesia. Hal itu membantu pelajar belajar bahasa Indonesia dengan cara hidup dalam budaya bahasa itu. Pembelajaran BIPA berbasis kearifan ekologis diharapkan menjadi bagian dari usaha internasionalisasi bahasa dan budaya Indonesia. Dengan demikian, pelajar BIPA tidak hanya menguasai kaidah bahasa saja tetapi mampu berkomunikasi sesuai konteks budaya Indonesia.

Menjadikan sebagai materi pengajaran merupakan bagian dari strategi revitalisasi yang menglobal terhadap kearifan ekologis di daerah ekspansi perkebunan sawit sehingga akan membukakan mata dunia melalui siswa asing bahwa perkebunan sawit telah mengubah aspek kemanusiaan dan kebudayaan. Harapannya tentu siswa asing akan berkontribusi pula terhadap usaha revitalisasi dan menjadi unjung tombak pelestarian kearifan itu di dunia global, setidaknya di negara mereka masing-masing.

\section{METODE PENELITIAN}

Penelitian ini menggunakan metode kualitatif. Pendekatan dilakukan mengikuti paham materialisme budaya, bahwa tradisi lisan (kearifan ekologis) dalam masyarakat merupakan struktur sosial yang bertujuan menjaga infrastruktur alam. Alam menyediakan sumber protein dan energi bagi masyarakat[2]. Oleh karena itu, harus ada norma yang mengatur tata hubungan manusia dengan alam. Masyarakat tradisional menyediakan metafora mitos dan legenda situs alam sebagai aturan.

Materialisme budaya adalah konsep teoritis yang dikemukakan oleh Marvin Harris. Harris menerapkannya dalam mengkaji logika pendewaan sapi dalam masyarakat penganut Hindu di India[2]. Sapi dijadikan dewa oleh tetua India adalah untuk menjaga dan melestarikan populasi sapi karena sumber protein susu sekaligus sumber tenaga pengolahan lahan pertanian. Populasi sapi dengan penduduk India tidak sebanding. Jumlah penduduk India berkembang dengan signifikan sementara perkembangbiakan sapi sangat lambat. Untuk itu dibuat aturan pelarangan makan daging sapi dengan menciptakan mitos bahwa sapi adalah jelmaan dewa dan dipercayai oleh masyarakat. Oleh karena itu, sapi tidak boleh dipotong untuk konsumsi. Begitu pula halnya mitos dan legenda ekologis di daerah ekspansi perkebunan sawit di Sumatra Barat. Di belahan bumi lain, seperti di Cina, leluhurnya telah menggunakan kearifan ekologis untuk menjaga harmoni hubungan alam dan manusia[3], dan jauh sebelumnya masyarakat tradisional telah menggunakan kebijaksanaan ekologis sebagai pedoman dalam kehidupan sosialnya[4]. 
Mitos dan legenda (karya sastra) dalam masyarakat tradisi mempunyai kedudukan yang setara dengan kitab suci[5]. Karya sastra merupakan alat pensucian jiwa (katarsis)[6], yang mengajarkan sensitifitas dan kepedulian pada lingkungan sekitarnya. Hal itu salah satu sebab mitos dan legenda menjadi sebuah kebenaran dan norma. Begitu kuatnya kekuatan nilai dalam cerita lisan itu, Finlandia, Cina, dan Rusia telah menggali folklor dan menjadikan nilai di dalamnya sebagai semangat kebangsaan. Negara-negara itu menjadikan cerita lisan itu sebagai sumber pembentukan kebudayaan modern mereka[7].

Oleh karena itu, lembaga pendidikan adalah institusi strategis penerusan kebudayaan. Bagi masyarakat lokal, lembaga pendidikan merupakan media penerusan kebudayaannya. Lain halnya bagi pelajar asing yang mengikuti BIPA, institusi pendidikan menjadi media untuk mengenal kebudayaan Indonesia. Maka, menjadikan kearifan ekologis sebagai materi pembelajaran BIPA merupakan hal yang urgen. Melalui pembelajaran BIPA diharapkan bangsa asing memahami fenomena budaya Indonesia sehingga tercipta pemaknaan total yang komprehensif.

\section{HASIL DAN PEMBAHASAN}

Tradisi lisan situs alam di daerah ekspansi perkebunan sawit di Sumatra Barat merupakan panorama bahasa dan sastra yang mengandung nilai-nilai ekologis. Hal itu terjalin dalam bentuk mitos dan legenda yang ada di sekitar perkebunan sawit. Mitos dan legenda itu menjadi bagian norma bagi masyarakat dalam berintegrasi dengan alamnya. Kearifan ekologis itu dapat digunakan sebagai pelajaran pada kehidupan. Terlepas dari logika modern, mitos dan legenda itu dapat digunakan sebagai pijakan dalam memahami dan berintegrasi dengan lingkungan dalam perspektif humaniora.

\subsection{Tradisi Lisan di Perkebunan Sawit}

Berdasarkan aspek historis, daerah ekspansi perkebunan sawit di Sumatra Barat merupakan tanah ulayat suku atau nagari. Hutan tersebut awalnya dikelola oleh nenek moyang yang merintis perkampungan. Di sana terdapat norma sosial, seperti hutan larangan. Norma itu diberi kekuatan magis dan dihidupi oleh masyarakatnya, seperti sanksi hukuman berupa "ke atas tidak berpucuk, ke bawah tidat berakar, di tengah dimakan serangga", atau jika masuk ke dalam hutan itu tanpa izin maka tidak dapat keluar dari hutan dan mengalami penderitaan.

Konvensi lisan itu mengatur prilaku manusia terhadap lingkungan yang sudah ada, menyesuaikan diri dengan kontur dan geografis alam, seperti yang dikatakan Steward[8]. Dalam ajaran tradisional Minangkabau berbunyi "di mana bumi dipijak di situ langit dijunjung". Selanjutnya, setiap orang tidak boleh mengganggu, merusak, dan mengubah struktur alam yang sudah ada, seperti ajaran "jika mandi di bawah-bawah", yang dianalogikan mandi di tepi sungai. Jika mandi di bagian hulu akan mengeruhi air orang lain yang sedang mandi terlebih dahulu. Manusia adalah pendatang di muka bumi dan alam sudah ada sebelumnya. Oleh karena itu, manusia harus menyesuaikan pola hidupnya dengan alam. Dampaknya, alam tidak rusak dengan datangnya manusia. Lain halnya hari ini, manusia datang ke hutan untuk mendapatkan sumber energi dan protein dengan cara mengubah kontur atau merusak[1].

Untuk melanggengkan konvensi tersebut nenek moyang secara tidak sadar menciptakan dan mengembangkan mitos-mitos yang terjalin dalam cerita lisan. Cerita itu berkembang dari generasi ke generasi berikutnya. Alam pikiran tradisional mempercayai isi cerita itu dan menjadi norma untuk berinteraksi dengan alam. Literasi itu kedudukannya dalam masyarakat tradisional sejajar dengan kitab suci. 
Ada banyak cerita lisan yang berkaitan dengan hutan rakyat dan tanah ulayat nagari dan suku. Bukit Tigo Sandiang dan Bacingkalak adalah dua contoh cerita lisan di hutan ulayat yang telah berubah jadi daerah ekspansi perkebunan sawit di Sumatera Barat. Cerita ini mengisahkan tentang keberadaan situs alam yang penting dalam masyarakat adat sebelum ekspansi.

\section{a. Bukik Tigo Sandiang}

Adalah sebuah bukit yang terdapat di perbatasan Kabupaten Agam dan Pasaman yang terletak antara tiga buah nagari, yakni Silareh Aia, Kinali, dan Tigo Nagari. Sandiang atau sisi bukit ini terdiri atas tiga bagian, yang masing-masing bagian menghadap kepada ketiga nagari tersebut. Masing-masing sisi bukit tersebut menjadi hutan ulayat masing-masing nagari. Tiga sisi hutan itu menjadi sumber protein, energy, dan papan bagi masyarakat nagari masingmasing. Aktivitas sosial dan budaya masyarakat nagari tersebut berada pada masing-masing sisinya.

Pada masa-masa tertentu bukit itu menjadi tempat ritual ketiga nagari tersebut. Ajang itu menjadi arena syukuran setelah panen, bersih desa, dan gotong royong membersihkan saluran air ke sawah menjelang bertanam. Di saat itu juga sekaligus menjadi ajang silaturahmi dan menyelesaikan konflik. Kadang kala juga menjadi ajang mencari jodoh bagi muda-mudi.

Berbagai aktifitas dan interaksi sosial masyarakat tiga nagari berpusat pada Bukit Tigo Sandiang. Terutama berkaitan dengan interaksi manusia dengan alam. Bukit tigo Sandiang menjadi sumber energi sosial dan kehidupan masyarakat. Selain itu, menjadi pusat tradisi masyarakat untuk meneruskan kehidupan dan keberlangsungan kebudayaan.

Berkaitan dengan situs ini terdapat berbagai cerita lisan, seperti Inyiak Akuan, Rimbo Uduhan, Batu Busuek, Si Ungko Putiah, dan Talago Peri. Tentu saja banyak cerita lain. Inyiak Akuan adalah cerita yang mengisahkan makhluk atau kekuatan gaib penjaga hutan. Masyarakat menyebutnya Inyiak Akuan. Salah satu versi cerita ini adalah Inyiak Akuan ini akan menampakan diri ke perkampungan. Jika ada yang melihatnya masyarakat meyakini itu tanda akan terjadi bencana. Inyiak itu datang untuk mengingatkan warga agar waspada. Versi lain, penampakkanya di kampung untuk mengawasi dan mengontrol prilaku masyarakat. Rimbo Uduhan adalah cerita tentang hutan yang memiliki kekuatan gaib. Jika ada warga atau orang lain yang masuk dan mengambil isi hutan tersebut tanpa izin dari Inyiak (tetua kampung), maka orang tersebut tidak dapat keluar. Orang tersebut akan tersesat atau berputarputar saja dalam hutan sekian lama. Dalam hutan itu orang mengalami berbagai penderitaan. Ada yang bertahan dan akhirnya keluar dalam keadaan fisik yang mengenaskan. Ada pula yang tidak bisa keluar dan sudah menjadi mayat ditemukan oleh pencari kayu dalam hutan.

Selanjutnya, cerita Si Ungko Putiah adalah cerita tentang kera besar berwarna putih yang hidup di atas bukit tersebut. Kera itu diyakini masyarakat sebagai jelmaan dari pasangan kekasih yang melanggar janji. Dalam perjanjian itu, jika di antara mereka ada yang melanggar maka akan berubah menjadi kera puth dan harus diusir dari kampung. Di hutan kera putih tersebut selalu menampakan diri jika ada manusia yang ingin berbuat salah dan merusak hutan sehingga mereka membatalkan niatnya.

Cerita Talago Peri adalah cerita tentang telaga yang terdapat di atas bukit tersebut. Di sekitar telaga itu dikelilingi oleh padang rumput. Telaga itu diyakini masyarakat sebagai tempat mandinya peri atau dewi yang turun ke bumi. Pernah warga melihat peri ketika mereka berkemah di sekitar telaga. Peri itu secara gaib menyuruh mereka kembali dan turun dari bukit, karena peri tersebut merasa terganggu. Cerita lain, ada warga yang mencoba masuk dan mengambil plasma nutfah di telaga itu dan tidak bisa kembali ke kampungnya. 


\section{b. Situs Bacingkalak}

Bacingkalak adalah situs alam yang terdapat di area perkebunan sawit. Situs ini merupakan cek dam tradisional dari alur sungai yang sudah ada. Air sungai itu digunakan untuk mengaliri areal persawahan. Oleh karena sungai posisinya rendah dibanding dengan sawah maka dibuat empang agar air tergenang dan meninggi sehingga dapat mengaliri persawahan. Empang itu dibuat oleh nenek moyang menggunakan bambu dan manau yang diambil dari hutan. Namun dam tersebut saat ini telah hancur dan disfungsional karena perubahan pola pertanian dari persawahan ke perkebunan sawit.

Untuk membuat dam tersebut dilakukan secara bergotong royong. Bersama-sama ke hutan mengambil materil dan membawanya ke tepi sungai. Selanjutnya, dilakukan pemancangan untuk menghambat aliran air sehingga menggenang dan dapat mengaliri sawah. Sebelum pekerjaan dilakukan dilaksanakan upacara penyembelihan hewan kurban berupa kambing. Kemudian di masak dan dimakan bersama-sama setelah selesai pengerjaan dam. Selanjutnya, dibuat kesepakatan bersama untuk menjaga dam dan segala isinya dengan sanksi-sanksi jika terjadi pelanggaran. Kesepakatan itu dikuatkan dengan doa bersama agar dam, sungai, air, dan plasma nutfah yang tumbuh dan berkembang di dalamnya bermanfaat dan menjadikannya sebagai sungai uduehan (larangan). Setelah kesepakatan itu diberlakukan muncul cerita tentang kejadian aneh di sekitar lokasi, seperti cerita peri mandi dan orang yang berputar-putar di pinggir sungai. Kejadian-kejadian tersebut dipercaya sebagai dampak uduehan.
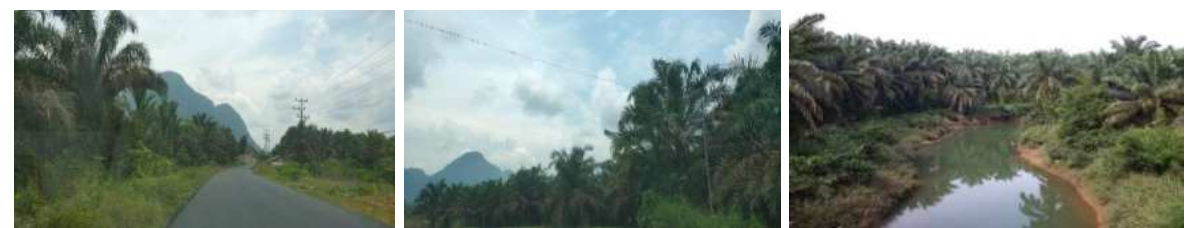

Gambar1 Situs Bukik Tigo Sandiang dan Bacingkalak di Area Ekspansi Perkebunan Sawit di Perbatasan Kabupaten Agam dan Pasaman Barat

(Dok. Khairil Anwar)

\subsection{Fungsi dan Makna Tradisi Lisan}

Cerita lisan pada dua situs alam di atas memiliki peran dan makna dalam kehidupan masyarakatnya. Adapun fungsinya adalah sebagai alat sosialisasi dan pendidikan, kontrol sosial, proyeksi masyarakat, dan pelestari ekologis.

Makna dan nilai dari tradisi lisan tersebut adalah penghargaan terhadap alam sebagai sumber energi dan protein bagi manusia. Manusia harus menempatkan alam sebagai mitologi dan kosmologi serta menyesuaikan diri dengan alam yang telah ada. Bukan seperti saat ini, manusia merusak alam yang didatanginya sehingga menjadi ancaman yang tidak pernah disadari manusia, kecuali ketika alam telah menimpa dalam bentuk bencana alam dan memusnahkan harta dan nyawa. Oleh karena itu, cerita lisan menawarkan nilai pelestarian alam. Artinya, menjaga alam menjaga keberlangsungan manusia dan masa depan bumi.

\subsection{Kearifan Ekologis Tradisi Lisan dalam Pembelajaran BIPA}

Berdasarkan pengalamannya mengajar BIPA di Tunisia, Widianto[9], menyimpulkan bahwa materi budaya Indonesia perlu diberikan agar pelajar mendapatkan rasa berbahasa Indonesia. Untuk itu, Pollard[10] menggunakan buku tradisi lisan dari berbagai daerah di Indonesia di Australia. Pollard menyimpulkan bahwa, di balik keunggulan dan kelemahan dalam pembelajaran tradisi lisan dapat digunakan sepanjang masa karena nilai universal. Bascom[11] menyatakan bahwa tradisi lisan itu bagian dari aspek kebudayaan dan berhubungan langsung dengan kehidupan mendasar, seperti kelahiran dan bencana alam. 
Materi tradisi lisan dalam pembelajaran itu bersifat pelengkap. Namun, menurut Pollard, tradisi lisan itu menjadi bagian penting dalam pengajaran itu. Sementara itu, pengalaman pelajar BIPA mengisyaratkan pentingnya muatan itu untuk percepatan penguasaan kemampuan berbahasa[12]. Di sisi lain, penggunaan multimedia bermuatan cerita tradisi lisan mempermudah pembelajaran bahasa Indonesia[13] [14].

Oleh karena itu, kearifan ekologis tradisi lisan di daerah perkebunan sawit dapat menjadi pelengkap bahan ajar BIPA sebab konteks dan substansi nilainya menjadi daya tarik. Pembelajaran itu akan lebih menarik dengan cara kunjungan ke situs alam tersebut sehingga pelajar dapat berinteraksi langsung dengan alam dan masyarakat.

\section{SIMPULAN}

Kearifan ekologis merupakan nilai-nilai yang terkandung dalam tradisi lisan di daerah ekspansi perkebunan sawit di Sumatera Barat. Tradisi lisan itu berkaitan dengan situs alam setempat. Tradisi lisan itu dan fenomena alam berserta kebudayaan yang terkait dengannya dapat dijadikan alternatif sebagai muatan ajar kontekstual dalam pembelajaran BIPA, baik dalam kelas maupun tour research ke perkebunan sawit tersebut. Sebab fenomena perubahan alam akibat ekspansi perkebunan sawit masih menjadi pembicaraan di dalam maupun di luar negri. Oleh karena itu, disarankan kepada pelaku pendidikan agar terus menggali kearifan ekologis di Indonesia dan sekaligus promosi kondisi alam di daerah ekspansi perkebunan sawit, serta bentuk revitalisasi kearifan ekologis ke generasi asing yang berkarakter green moral. Sebaliknya, pembelajar BIPA dapat dijadikan duta green moral bagi generasi muda dan bangsa Indonesia dalam melakukan pembangunan berkelanjutan.

\section{REFERENCES}

[1] H. Purwanto, Kebudayaan dan Lingkungan Dalam Perspektif Antropologi. Yogyakarta: Pustaka Pelajar, 2010.

[2] S. K. Sanderson, Sosiologi Makro. Jakarta: Rajawali Press, 1993.

[3] Z. SUN, Yuan and WANG, "The Harmonious Relationship Between Nature and Human-The Ecological Wisdom of Chinese Ancestors in Yuan Dao," J. Tangshan Coll., vol. Vol.4., p. 013, 2006.

[4] Z. Jian, "Ecological Wisdom and Its Enlightenment in Chinese Traditional Culture and Life," J. Nanjing For. Univ. (Humanities Soc., vol. Vol 03, p. 07, 2009.

[5] R. W. dan A. Warren, Teori Sastra. Jakarta: Gramedia, 1989.

[6] A Teew, Sastra dan Ilmu Sastra. Jakarta: Gramedia, 1984.

[7] J. Danandjaja, Folklor Indonesia: Ilmu Gosip, Dongeng, dan Lain Lain. Jakarta: Pustaka Grafitipers, 2002.

[8] J. H. Steward, Theory of Culture Change. Urbana: University of Illionis, 1955.

[9] E. Widianto, "Wayang Mini Dalam Pembelajaran Keterampilan Berbicara Bagi Pembelajar Bipa A1 Universitas Ezzitouna Tunisia," J. Kredo, vol. Vol 1 No., pp. 120-143, 2017.

[10] Nani Pollard, "Pengajaran Bahasa Indonesia untuk Pembelajar Asing melalui Cerita Tradisi Lisan," 2003.

[11] Bascom. W.R, "The Form of Folklore: Prose Narratives.," J. Am. Folk., no. The Hague: Mouton., 1965.

[12] D. Sudaryanto, "Literasi Mahasiswa Bipa Program Darmasiswa Universitas Ahmad Dahlan Bermuatan Bahasa Dan Budaya Indonesia," Jubindo J. Ilmu Pendidik. Bhs. dan Sastra Indones., vol. Vol 3, No, pp. 57-66, 2018.

[13] N. D. Setyaningsih, "Materi BIPA Berbasis Multimedia Dan Berkonten Budaya 
Lokal,” J. Cult., vol. Vol.3 No.1, p. hal 42-63, 2016.

[14] K. Saddhono, "Integrating culture in Indonesian language learning for foreign speakers at Indonesian universities,” J. Lang. Lit., vol. 6, no. 2, 2015. 